\title{
The Influence of Proximate Composition of Cow Dung on the Rate and Volume of Biogas Generation in Maiduguri, North Eastern Nigeria
}

\author{
Yerima $^{1}$, I.; Y.M. Ngulde'; Abubakar Mustapha ${ }^{3}$; A.L. Ngala ${ }^{4}$ \\ 1,2,3 Department of Biological Sciences, University of Maiduguri, Maiduguri, Nigeria \\ ibrahimyerima32@gmail.com \\ yunusamaina700@yahoo.com \\ mustafaabubakar3363@gmail.com \\ ${ }^{4}$ Department of Soil Science, University of Maiduguri, Maiduguri, Nigeria \\ adamngala@yahoo.com
}

\begin{abstract}
This research investigates the Cow dung, Cow pats or Cow pies as a waste product of Cattle which constitute undigested residue of plant material and excreted by the animal as a waste. One dung cake made by hand of an average size gives $2100 \mathrm{kj}$ of energy. The organic waste can be a source of renewable energy for rural areas especially in developing countries like Nigeria provided the material is subjected to anaerobic digestion to produce biogas as a means of waste disposal and alternative source of energy. Before this initiative of digesting Cow dung, the waste material is used as a direct fuel in clay stoves or three stone stoves and traditional fertilizer among peasant farmers in Nigeria and Asian countries. However, when discovered as a cheap, reliable and safe source of domestic fuel, energy experts and consumers thought of commercializing and patenting the gas.

The research was carried out in the Laboratory of the Department of Biological Sciences, University of Maiduguri, Nigeria, using the batch system digester with a capacity of0.612 $\mathrm{m}^{3}$ and $0.24 \mathrm{~m}^{3}$ as gasholder. About 0.2773 $\mathrm{m}^{3}$ of gas was released daily to control the excess pressure imposed on the gas holder (size 24, tractor tube). Laboratory and field analysis of the cow dung were carried out, followed by daily records of the volume of gas generated using ruler to measure and estimate the volume of the gas in cubic meter using the standard formula for measuring a cylinder $\left(3.14 \times r^{2} \times h\right)$. The result of this research shows that the gas generated was methane due to combustion in combination with Carbon dioxide $\left(\mathrm{CO}_{2}\right)$ due to non-combustion, Hydrogen Sulphide $\left(\mathrm{H}_{2} \mathrm{~S}\right)$ due to rotten egg smell and water vapor. The daily volume of biogas generated was $0.27915 \mathrm{~m}^{3}$ on the average, with a maximum daily record of $0.5165 \mathrm{~m}^{3}$ before declining after 73 days of
\end{abstract}

the experiment and a cumulative volume of $77.62 \mathrm{~m}^{3}$ in 52 days of methane production. The sustainability of cooking trial utilized an overall volume of $1.17 \mathrm{~m}^{3}$ of the methane gas in $1 \mathrm{hr}$ to cook $1.5 \mathrm{~kg}$ of rice with ingredients and 0.553 $m^{3}$ in 1:35 hrs.to boil 20 liters of water. The digestion process was done in an airtight drum of $0.612 \mathrm{~m}^{3}$ capacity as the digester.

Keywords- Biogas, methane, cow dung, bio-fertilizer, inoculum, carbondioxide, stove and sustainability.

\section{INTRODUCTION}

The potential value of Cow dung and it's by products produced by the meat industry, theMaiduguri abattoir as a waste material or source of renewable energy, bio fertilizer and animal feed has been neglected by the urban community and researchers. This is indicated by the heaps of cow dung at the Maiduguri abattoir, diversion of the material to farmlands before treatment, dumping of the waste material in the nearest river and lack of scientific journals, reports or research carried out on the waste material by local scientists in Maiduguri, the Borno State capital. A related activity is the collection and dumping of the raw waste material by farmers to their farmlands as a manure to supplement the traditional inorganic fertilizer, which is expensive and polluting to the environment (Smith and Slater, 2010). This is because in most developing countries like Nigeria recycling of waste or agricultural wastes are rarely practiced leading to pollution and environmental degradation (Yahaya and Ibrahim, 2012).In Nigeria this scenario is sometimes promoted by ignorance of the value and accessibility to the organic material, thereby making fuel wood as the only source of fuel for domestic purpose for majority of the people living in the 
region thereby creating unnecessary pressure on the already degraded land.It is noteworthy that, due to lack of provision for alternative source of energy like solar, wind and nuclear energy, fuel wood or biomass as the only traditional fuel remains inaccessible and expensive in Maiduguri, primarily due to insecurity, in addition to demand by the increasing human number, loss of vegetation, aridity or deforestation, high cost of fossil fuel, decreased supply of fuel wood, reduced crop residues, inefficient cooking devices or stoves and poor construction materials.This has created a lot of pressure on the already degraded arid environment. This phenomenon informs us that cow dung must be seriously looked into as a valuable alternative source of domestic energy for the rural poor community.

The main energy requirement in the ecological zone include domestic cooking, heating, warming during the cold harmatan period, small scale food processing industries and lighting in rare cases. Domestic homes in the urban areas have been using firewood, kerosene or electricity for their fuel requirement in homes and industries, while in the rural areas, particularly in the extreme northern arid zone of the region, these fuel materials are not accessible or completely not available due to acute aridity, loss of vegetation and where available they are expensive. Due to domestic pressure and necessity, the alternative fuel has always been the slashed twigs and branches of the sparsely populated trees, shrubs of the pois onous plant Calotropis procera, cake of dung or expensive fuelwood imported from the city. It was reported that by 2050 the rural energy needs of Africa would be the traditional source of rural energy like forest biomass, wood and agricultural residues (Revelle, 1979).

This research, therefore intends to use cow dung as an alternative source of energy to produce biogas (methane) as a source of fuel for use in the rural areas of Nigeria particularly in the dry land zones in the northern part of the country. The gas has a number of advantages to the economy of a nation like Nigeria, which include reduction of dependence on imported or using petroleum gas, protecting the environment by minimizing greenhouse gas emissions(Torguati, et al.,2014). It will also empower the rural community by savingabout 144 minutes of their time from wood collection (Amare, 2015), the economy of a nation, the security of women and children during fuel collection in the bush and also children will have enough time to go to school. Biogas or methane production reduces the effect of deforestation caused by fuel wood extraction and climate change in Nigeria (Maiwada,et al.,2014), increased biomass yield from the use of biogas slurry as bio-fertilizer(Kasap, et al, 2012) and it also gives more time to vegetation to sprout and regrow. The nutrient rich sludge after digestion is recycled back to the land to maintain the fertility of the field growing feed for the cows at Mason-Dixon Dairy Farm located at Gettysburg, Pennsylvania (www.manuremanagement.cornell,2017). This suggest that the structure and components of biogas generation put in a community must be monitored for use and effectiveness in the community (Nagamani and Ramasamy, 1990).

In Vietnam the biogas potential is due to livestock of more than 30 million, mostly pigs, cattle, and water buffalo. Although most of the livestock dung is used in feeding fish and fertilizing fields and gardens (Zafar, 2012). At the Mason-Dixon Dairy Farm located near Gettysburg, Pennsylvania manure from 2000 cows produced fuel engines that drive generators supplying not only all the electrical power for the Dairy, but the excess is sold to the utility company where the waste heat from the engine is used to heat the digester and the building (www.management.cornell,2017). Besides the benefits derived from biogas, it has some negative consequences on human health when used indoors. The gas is a major cause of respiratory morbidity for women and children (Dohoo, et al.2012)

Considering the above background this research intends to determine the influence of the proximate composition of cow dung and the rate of methane production during the season in the zone as its aim and objective and to specifically determine the volume of gas generated per unit time, the cumulative volume of gas per sludge of cow dung, the amount of gas required to sustain a cooking time and number of people in a family. Biogas or methane gas $\left(\mathrm{CH}_{4}\right)$ is referred to as a biofuel, because it is generated from degradable biological material. The gas is primarily made up of methane $\left(\mathrm{CH}_{4}\right) 55-70 \%$, Carbon dioxide $\left(\mathrm{CO}_{2}\right) 30-$ $45 \%$, with some amount of other gases like hydrogen sulphide $\left(\mathrm{H}_{2} \mathrm{~S}\right) 1-2 \%$ and traces of hydrogen $\left(\mathrm{H}_{2}\right) 0-1 \%$, Nitrogen $\left(\mathrm{N}_{2}\right) 0-1 \%$, carbon monoxide $(\mathrm{CO})$, saturated or halogenated carbohydrates in traces and oxygen $\left(\mathrm{O}_{2}\right)$ traces which are occasionally present in the gas. This was confirmed byOnwuliri(2013) who reported that, the composition of the gas methane gas is $\left(\mathrm{CH}_{4}\right) 50-70 \%, \mathrm{CO}_{2}$ $30-40 \%$ and other gases. It wasfurther reported that the composition of biogas depends on the type of decomposedmaterial, which may be as follows $50-85 \%$ methane $\left(\mathrm{CH}_{4}\right), 20$ - 35\% Carbon dioxide $\left(\mathrm{CO}_{2}\right), \mathrm{H}_{2}, \mathrm{~N}_{2}$ and $\mathrm{H}_{2} \mathrm{~S}$ form the rest of the composition(Pastorek et al.,2004) (Bharathiraja,2018). Usually the mixture is saturated with water vapor and may contain dust, some impurities and siloxane. According to Lawbury(2001) approximately $60 \%$ 
methane, $40 \% \mathrm{CO}_{2}$ with traces of other gases like hydrogen, nitrogen and hydrogen Sulphate are present.

Depending on the appliance used, the quantity of biogas has to be improved, due to interference by aeration and moisture. The Biogas Project(BP) (2015) reported that in order to upgrade the system and the quality of the gas some parameters like hydrogen Sulphate, water vapor, carbon dioxide, and halogenated compounds need to be removed. This will allow the gas to burn with blue flame, stable, nontoxic, tasteless and odorless. The presence of hydrogen Sulphate is noticed by a percentage of rotten egg smellwhen burned. When the gas burn in the presence of oxygen it produces a blue flame and large amount of heat energy and due to the presence of $\mathrm{CO}_{2}$, this makes the fuel safe for use in rural homes as domestic fuel for cooking, heating and generation of electricity because it is not explosive like petroleum gas.

Cow dung is obtained from a cow, where about 50 liters of methane can be generated from a single cow after chewing the cud. The benefit of biogas generation is not only the biofuel and environmental sanitation but an organic fertilizer called bio-fertilizer or slurry is generated for use by farmer, especially when inorganic fertilizer is beyond the farmer's reach. The application of the slurry to soil is equal to bioremediation process of disposing excess nitrogen from animal farm and injecting it into crop land (Lopez-Ridaura, et al,2009). Further to this, the bio-fertilizer slurry improves the nutrient status of the soil, where it influenced the production of $5 \mathrm{t} / \mathrm{ha}$ of crop compared to inorganic fertilizer (Shaheb et al.,2015). Likewise, the physical properties of soil such as structure, texture, water holding capacity, cation exchange capacity and less erosion could be corrected or influenced by bio-fertilizer(Gurung, 1997)

\section{MATERIALS AND METHOD}

The experiment was carried out in the Faculty of Science Complex(UsienUdom Court) of University of Maiduguri, Nigeria, after collecting the required amount of cow dung from the Maiduguri abattoir on the $02 / 08 / 18$ in a polythene bag and kept airtight to prevent loss of moisture and contamination.

\section{Generation of Biogas(Methane)}

Twenty four hours after collection of cow dung from the Maiduguri abattoir,400 $\mathrm{kg}$ of the cow dung was weighed using a weighing balance(Saltare model) and 400 liters of inoculum measured in a measuring cylinder $\left(1000 \mathrm{~cm}^{3}\right)$ was fed in to a batch digester(bioreactor) with a capacity of $0.612 \mathrm{~m}^{3}$, after it wasanalyzed for proximate composition such as moisture content using moisture
analyser(METTLER TOLEDO LJ16 and LP16 MODEL), $\mathrm{Ph}$. using Ph.Meter(PHS-25 MODEL) and the temperature of the digester using a thermometer $\left(0-100^{\circ} \mathrm{C}\right.$ capacity $)$ and the ash content was determined using an oven (Hot Air Oven). The $400 \mathrm{~kg}$ of Cow dung was homogenized to have fine and well separated particles to improve on the rate of digestion by the methanogen bacteria, 4000 liters of water were added to the quantity of cow dung to give a ratio of 10:1 water: cow dungAnjos et al. (2017) used batch digesters with and without solid separation in the substrates, Ezekoye et al.(2014) used cow dung to water in a ratio of 6:1. After feeding the digesterit was allowed to ferment, hydrolyze and methenation at a mesophyll temperature range of $38^{\circ} \mathrm{C}$ for a period of 14 days before a noncombustible gas was generated.

\section{Carbon dioxide Scrubbing}

The non-combustible gas generated was collected in a tractor tube of size 24 as an alternative gasholder for convenience of measurement and movement of gas from place to place by the end user in laboratories and rural community.From the $15^{\text {th }}$ day to the $35^{\text {th }}$ of the experiment an average of $0.1657 \mathrm{~m}^{3}$ of thegas wasgenerated but notcombustible, so it was suspected to be carbon dioxide together with hydrogen Sulphate due to the rotten egg smell perceived, and it was expelled from time to time to time to reduce the pressure on the gas collector and the scrubbed carbon dioxide was injected in to water as waste for the growth of algae by another research.

\section{The Gas Burning Flame}

The nature of the burning flame was observed for colour and the existence of soot deposits and possible moisture from the burner.

\section{The Combustible Gas (Methane)}

The combustible gas, flame type and smoke observed and notedon the $36^{\text {th }}$ day of the experiment and this was measured and recorded as methane gas. Daily records of the gas was taken and recorded for the period of 87 days of the experiment. The volume of gas generatedwas measured using a metric rule and substituted in the standard formula of measuring a cylinder( $\left.3.14 \mathrm{x} \mathrm{r}^{2} \mathrm{xh}\right)$ and recorded with daily room temperature as indicated in Table 1 , while the volume of gaswas plotted in a graph (fig.1).

The values in cubic centimeter were divided by one million to give a volume measurement in cubic meter. 
A graph showing the varying height of the gas was shown in figure 1 , with a histogram at the background.

\section{RESULT AND DISCUSSION}

The result of this research indicates that gas production started14 days after feeding the digester, but it was not combustible and it was assumed to be carbon dioxide $\left(\mathrm{CO}_{2}\right)$ with other gases like hydrogen sulphate $\left(\mathrm{H}_{2} \mathrm{~S}\right)$ due to the rotten egg smell and water vapor during scrubbing. A similar trend was observed by Ezekoyeet al. (2014) where about 156.21 liters of the gas from waste material was produced after a period of 75 days with the methane constituting only $52.3 \%$ and combustible on the $45^{\text {th }}$ day of the experiment. In this research the carbon dioxide exceeded the methane production on the $36^{\text {th }}$ of the experiment when methane gas increased above carbon dioxide and reached its peak with a volume of $0.5165 \mathrm{~m}^{3}$ of gas on the $73^{\text {rd }}$ day before declining, when room temperature was $31^{\circ} \mathrm{c}$, although it has no influence on the rate of gas production, as indicated in the table below(table 1). In another research gas production started after $7^{\text {th }}$ day with a steady increase and attend its peak on the $18^{\text {th }}$ day before declining(Ugochukwu et al. (2018). From the above scenario it can be deduced that the time and volumeof initial methane production is determined by the type material and other secondary factors used as a substrate for the production of the gas.

Table.1: Showing the Daily Volume of Gas Generated and Room Temperature Recorded

\begin{tabular}{|l|l|l|l|}
\hline $\begin{array}{l}\text { Seri } \\
\text { al } \\
\text { no. }\end{array}$ & Date/Days & $\begin{array}{l}\text { Volume } \\
\text { Biogas } \\
\text { generated/day } \\
\left(\mathrm{M}^{3}\right)\end{array}$ & $\begin{array}{l}\text { Daily } \\
\text { Temperature }\left({ }^{0} \mathrm{C}\right)\end{array}$ \\
\hline 1 & $03 / 08 / 18$ & - & 26 \\
\hline 2 & $04 / 08 / 18$ & - & 27 \\
\hline 3 & $05 / 08 / 18$ & - & 29 \\
\hline 4 & $06 / 08 / 18$ & - & 28 \\
\hline 5 & $07 / 08 / 18$ & - & 28 \\
\hline 6 & $08 / 08 / 18$ & - & 29 \\
\hline 7 & $09 / 08 / 18$ & - & 30.5 \\
\hline 8 & $10 / 08 / 18$ & - & 29 \\
\hline 9 & $11 / 08 / 18$ & - & 26 \\
\hline 10 & $12 / 08 / 18$ & - & 30 \\
\hline 11 & $13 / 08 / 18$ & - & 34 \\
\hline 12 & $14 / 08 / 18$ & - & 31 \\
\hline 13 & $15 / 08 / 18$ & 0.1657 & 31 \\
\hline 14 & $16 / 08 / 18$ & 0.1657 & 31 \\
\hline
\end{tabular}

\begin{tabular}{|c|c|c|c|}
\hline 15 & $17 / 08 / 18$ & 0.1657 & 29.9 \\
\hline 16 & $18 / 08 / 18$ & 0.1657 & 27 \\
\hline 17 & 19/08/18 & 0.1657 & 39 \\
\hline 18 & $20 / 08 / 18$ & 0.1657 & 33 \\
\hline 19 & $21 / 08 / 18$ & 0.1657 & 30 \\
\hline 20 & $22 / 08 / 18$ & 0.1657 & 30 \\
\hline 21 & $23 / 08 / 18$ & 0.1657 & 31 \\
\hline 22 & $24 / 08 / 18$ & 0.1657 & 29.9 \\
\hline 23 & $25 / 08 / 18$ & 0.1657 & 25.5 \\
\hline 24 & $26 / 08 / 18$ & 0.1657 & 39.5 \\
\hline 25 & $27 / 08 / 18$ & 0.1657 & 32.5 \\
\hline 26 & $28 / 08 / 18$ & 0.1657 & 29.5 \\
\hline 27 & $31 / 08 / 2018$ & 0.0 .1657 & _- \\
\hline 28 & $01 / 09 / 2018$ & 0.1657 & - \\
\hline 29 & $02 / 09 / 2018$ & 0.1657 & _- \\
\hline 30 & $03 / 09 / 2018$ & 0.1657 & - \\
\hline 31 & $04 / 09 / 2018$ & 0.1657 & - \\
\hline 32 & $05 / 09 / 2018$ & 0.1657 & _- \\
\hline 33 & $06 / 09 / 2018$ & 0.1657 & - \\
\hline 34 & $07 / 09 / 2018$ & 0.2862 & _- \\
\hline 35 & $08 / 09 / 2018$ & 0.2566 & - \\
\hline 36 & 09/09/2018 & 0.3020 & _ \\
\hline 37 & $10 / 09 / 2018$ & 0.3155 & 27 \\
\hline 38 & $11 / 09 / 2018$ & 0.2722 & 29 \\
\hline 39 & $12 / 09 / 2018$ & 0.2739 & 30 \\
\hline 40 & $13 / 09 / 2018$ & 0.3212 & 28 \\
\hline 41 & $14 / 09 / 2018$ & 0.3588 & 28 \\
\hline 42 & $15 / 09 / 2018$ & 0.2579 & 30 \\
\hline 43 & $16 / 09 / 2018$ & 0.2821 & 31.5 \\
\hline 44 & $17 / 09 / 2018$ & 0.3125 & 29 \\
\hline 45 & $18 / 09 / 2018$ & 0.2475 & 26 \\
\hline 46 & $19 / 09 / 2018$ & 0.2678 & 30 \\
\hline 47 & $20 / 09 / 2018$ & 0.2929 & 34 \\
\hline 48 & $21 / 09 / 2018$ & 0.3337 & 31 \\
\hline 49 & $22 / 09 / 2018$ & 0.3237 & 32 \\
\hline 50 & $23 / 09 / 2018$ & 0.3128 & 32 \\
\hline 51 & $24 / 09 / 2018$ & 0.4166 & 29.9 \\
\hline 53 & $25 / 09 / 2018$ & 0.3432 & 25.5 \\
\hline 54 & $26 / 09 / 2018$ & 0.2843 & 30.5 \\
\hline 55 & $27 / 09 / 2018$ & 0.3343 & 33.5 \\
\hline 56 & $28 / 09 / 2018$ & 0.2926 & 29.5 \\
\hline 57 & $29 / 09 / 2018$ & 0.3368 & 31.5 \\
\hline 58 & $30 / 09 / 2018$ & 0.2533 & 32.5 \\
\hline 59 & $01 / 10 / 2018$ & 0.2934 & 34 \\
\hline 60 & $02 / 10 / 2018$ & 0.3127 & 30 \\
\hline 61 & $03 / 10 / 2018$ & 0.2777 & 28 \\
\hline 62 & $04 / 10 / 2018$ & 0.3013 & 29.9 \\
\hline 63 & $05 / 10 / 2018$ & 0.2978 & 31.0 \\
\hline
\end{tabular}




\begin{tabular}{|c|c|c|c|c|c|c|c|}
\hline 64 & $06 / 10 / 2018$ & 0.3135 & 31.5 & 84 & $26 / 10 / 2018$ & 0.1223 & _- \\
\hline 65 & $07 / 10 / 2018$ & 0.3369 & 29.0 & 85 & $27 / 10 / 2018$ & 0.0323 & 38.0 \\
\hline 66 & $08 / 10 / 2018$ & 0.3439 & 31.0 & 86 & $28 / 10 / 2018$ & 0.0384 & 35.0 \\
\hline 67 & $09 / 10 / 2018$ & 0.3408 & 33.0 & 87 & $29 / 10 / 2018$ & 0.0353 & - \\
\hline 68 & $10 / 10 / 2018$ & 0.3593 & - & 88 & $30 / 10 / 2018$ & 0.0355 & - \\
\hline
\end{tabular}

Throughout the period of methane generation there was a continuous daily fluctuation as indicated in figure 1 . The fluctuation in gas production particularly the syncline indicated in figure 1 was attributed to a number of factors operating in the digester such as the high acidic condition of the digester with a $\mathrm{Ph}$. value of 3.8 , high moisture content raw material, incomplete digestion of materials and lower digester temperature. These factors were naturally controlled intermittently and more remittent on $72^{\text {nd }}$ day, 24 hours before the peak. This volume of gas generated was not influenced by the daily measurement of temperature as indicated in table 1 above.Therefore, controlling the factors responsible for the intermittent gas production could give a steady and high gas production.

\section{Chart Title}

100

90

80

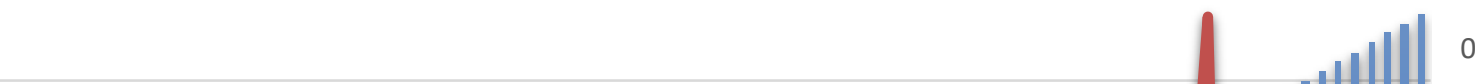

70

60

50
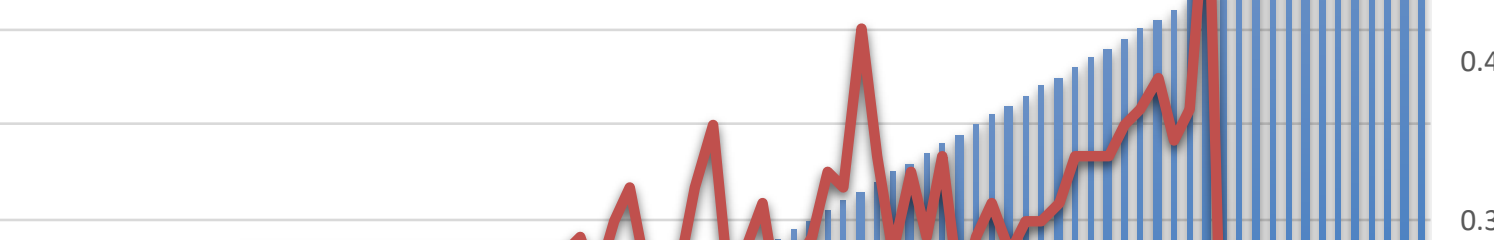
1

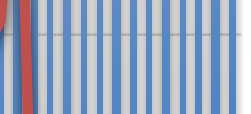

40

30

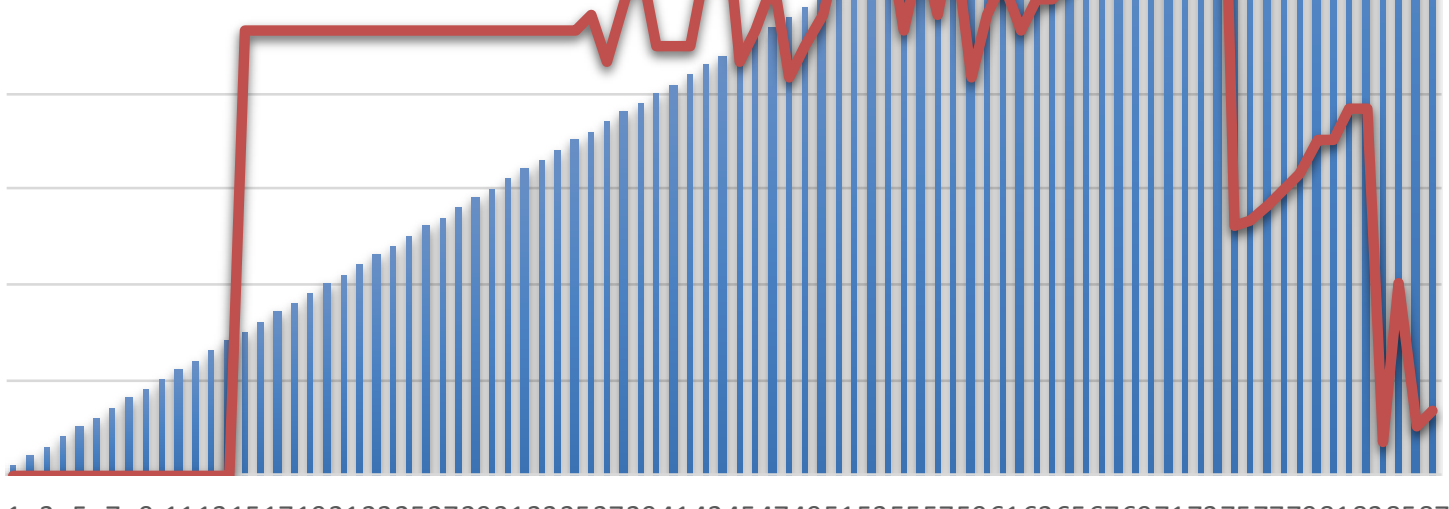

0.3

13579111315171921232527293133353739414345474951535557596163656769717375777981838587

Fig.1: Showing the daily rate of Biogas production 
In this research the percentage composition of the gas was not measured, but the cow dung was well composted in order to produce the expected proportion of gas as obtained by other researchers on biogas. The composition of biogas depends mostly on the type of decomposed material, unless otherwise, the composition of biogas is 50-85\% methane $\left(\mathrm{CH}_{4}\right), 20-30 \%$ Carbon dioxide $\left(\mathrm{CO}_{2}\right)$, Nitrogen $\left(\mathrm{N}_{2}\right)$, and Hydrogen Sulphate $\left(\mathrm{H}_{2} \mathrm{~S}\right)($ Pastorek et al., 2004), $60 \%$ methane $40 \%$ Carbon dioxide with other gases like hydrogen, Nitrogen and Hydrogen Sulphate(Lawbury, 2001).
The combustible methane was connected to a single stove burner and ignited for a cooking trial and sustainability based on an average daily production of $0.2773 \mathrm{~m}^{3}$ of gas. Besides the triode peaks there was a number of fluctuations throughout the period of the 87 days of observation and record of value. A drastic decline in production of $0.5165 \mathrm{~m}^{3}$ to $0.1550 \mathrm{~m}^{3}$ was recorded on the $74^{\text {th }}$ day of the experiment. A similar trend was observed by (Ugochukwu et al,2018). The series of fluctuation in the daily production throughout the experiment could be ascribed to the high acidic condition ( $\mathrm{PH}$ 3.8) of the digester as indicated in Table 2

Table.2: Showing the Composition of the Digester

\begin{tabular}{|l|l|l|l|l|l|l|l|}
\hline $\begin{array}{l}\text { Quantity of } \\
\text { waste }(\mathrm{kg})\end{array}$ & $\begin{array}{l}\text { Quantity of } \\
\text { water } \\
(\mathrm{L})\end{array}$ & $\begin{array}{l}\text { Quantity of } \\
\text { Innoculum } \\
\text { (L) }\end{array}$ & $\begin{array}{l}\text { Moisture } \\
\text { content }(\%)\end{array}$ & $\begin{array}{l}\text { Ash } \\
\text { content }(\%)\end{array}$ & $\begin{array}{l}\text { Ph value of } \\
\text { slurry }\end{array}$ & $\begin{array}{l}\text { Ph value of } \\
\text { raw cow } \\
\text { dung }\end{array}$ & $\begin{array}{l}\text { Cumulative } \\
\text { Volume of } \\
\text { gas generated } \\
\left(\mathrm{m}^{3}\right)\end{array}$ \\
\hline 400 & 4000 & 400 & 48 & 48.7 & 3.8 & 6.8 & 77.62 \\
\hline
\end{tabular}

Hyper acidic condition in a digester caused by factors like overload, low nutrient content of cow dung (Friedmann,2015),fermentation process and acidification during methenation was found to reduce biogas production (Chibueze et al,2017). The second factor that was associated with the fluctuation in production was high moisture content, which was high in this research(48\%) Table 2.Lungkhimba et al. (2010) reported that use of high moisture content material, incomplete digestion and low temperature was responsible for lower gas yield. Also finer particle size can lead to acidification and ultimately to process failure at highest organic load rate. The cow dung collected from the field had a PH value of 6.8 which was near neutral, however when it was fed into the digester the process of hydrolysis was releasing more hydrogen ions which was not taken up by the carbon from the organic matter or cellulose from the cow dung. The carbon released was combining with the available oxygen to produce the excess carbon dioxide that was experienced $\left(0.1657 \mathrm{~m}^{3}\right)$ for a period of 21 days. Methane was later generated when oxidation was replaced by reduction and hydrogen ions combining with carbon to form methane gas which it lasted for the whole period of the experiment(Table 1and Figure1).

\section{Performance on Water Boiling Test}

The cumulative period of gas generation was subjected to Kitchen trialby boiling 20 liters of water and the result obtained are shown in the table, table 3 below. The total cumulative volume of methane gas generated was $77.62 \mathrm{~m}^{3}$, out these the trial utilized $0.553 \mathrm{~m}^{3}$ of the gas in 1:35 hours to boil 20 liters of water (table 3). This means during the cold season the demand for hot water for bath and other purposes can be attain to using biogas to save the rural people from cold and diseases associated with it.

Table.3: Showing Sustainability trial of boiling water

\begin{tabular}{|l|l|l|}
\hline $\begin{array}{l}\text { Quantity of water } \\
(\mathrm{L})\end{array}$ & $\begin{array}{l}\text { Volume of Biogas } \\
\text { utilized }\left(\mathrm{m}^{3}\right)\end{array}$ & Time taken (hrs) \\
\hline 20 & 0.553 & $1: 35$ \\
\hline
\end{tabular}

\section{Performance on the Cooking Trial}

The cooking trial was done with rice and the necessary ingredients for a family of thirteen as part of sustainability of the gas generated. The total cumulative volume of methane generated was $77.62 \mathrm{~m}^{3}$, out of these the cooking trial utilized $1.17 \mathrm{~m}^{3}$ of the gas in lhour to cook the rice with ingredients and 10 liters of water to serve 13 plates of rice as lunch to 13 men and women with satisfaction (table 4). This indicate that using the biogas for a family of sixteen has saved the environment from loss of vegetation through fuel wood extraction, which has been recognized as means of cooling houses. This is because rural areas of developing countries are dependent on biomass fuels like fuel wood and dried dung for their energy need. For example, in Kaduna State of Nigeria Fuel wood accounts for about 1,722,904 $\mathrm{t} /$ year/person (Zaku et al, 2013). Therefore, if biogas can be introduced in Kaduna as an alternative the state could be saved from deforestation due fuel wood extraction, raping of women and danger of going to the bush to search for fuel, children going to search for fuel during school hours, 
excessive carbon dioxide due to poor type of fuel wood and inefficient and poorly constructed cooking devices.

It was further reported that $83 \%$ of renewable is consumed in Nigeria and the greater part of it is fuel wood (UNDP, 2002), with a daily fuel wood consumption in Nigeria estimated at 27.5 million $\mathrm{kg} /$ day(Ogunsawa,2002). From the volume of biogas generated in this research Nigeria can institute a biogas use scheme in the country to reduce the rate of environmental degradation.

Table.4: Sustainability trail of cooking rice with ingredients

\begin{tabular}{|l|l|l|l|}
\hline $\begin{array}{l}\text { Quantity of } \\
\text { Rice (kg) }\end{array}$ & $\begin{array}{l}\text { Quantity of } \\
\text { water } \\
\text { utilized (L) }\end{array}$ & $\begin{array}{l}\text { Volume of } \\
\text { Gas utilized } \\
\left(\mathrm{m}^{3}\right)\end{array}$ & $\begin{array}{l}\text { Time taken } \\
\text { (hrs.) }\end{array}$ \\
\hline 1.7 & 10 & 1.17 & 1 \\
\hline
\end{tabular}

\section{CONCLUSION}

Therefore, from this research it can be concluded that cow dung as a waste material can be a source of wealth to a nation; especially in developing countries where the traditional source of domestic energy has been fuel wood without alternative which was contributing to deforestation, climate change, desertification and loss of soil fertility. However, this research observed that the most appropriate cooking stove must be employed to attain a sustainable level of benefit. Also in order to attain high and steady yield of gas production a number of factors like high moisture content of raw material, highacidity of digester, incomplete digestion and lower temperature must be avoided. Other benefits of biogas production like the sludge or slurry obtained could serve as bio-fertilizer to amend soil fertility of a degraded land. Also with the appropriate device, a sustainable electricity power can be generated as energy for the animal house and the excess can be sold to neighboring energy demand. It can be concluded that rearing of cows in a community can be source of income and poverty alleviation not only for milk and meat but energy and fertilizer. Finally, it can be concluded and advised that due to high ash content of $48.7 \%$ in raw cow dung it is not economical to use the raw cake as fuel.

\section{ACKNOWLEDGEMENT}

We wish to acknowledge the Tertiary Education Trust Fund (TETFUND) at national body and the University of Maiduguri, Research and Innovation Centre for their immense financial support, encouragement and monitoring throughout the period of the experiment. This acknowledgement will be incomplete without saying thank you to the Department of Biological Sciences for the space supporting stafff and some facilities that were not procured by the TETFUND. The contributions of the following members of staffin the field during the trying period cannot be forgotten Mohammed Ali, Sale Hamma, Juliana Adamu and Bakolo. We say thank you all.

\section{REFERENCES}

[1] Amare, Z.Y. (2015) The Benefits of the Use of Biogas Energy in Rural Areas in Ethiopia: A Case Study from the AmharaNational Regional State, Fogera District. Academic Journals.Vol. 9 (4), pp.332 - 345 April 2015.http://www.academicjournals.org/AJEST.

[2] Anjos, I. D., Toneli, J.T.C.L., Sagula, A.L., Sagula, A.l. and Junior, J.de (2017) Biogas Production in Dairy Cattle System: Using Batch Digesters with and Without Solids Separation in the Substrate. Eng. Agric. Vol. 37 no.3 Jaboticabal May/ June 2017 http://dx.doi.org.

[3] Bharathiraja, B., Sudharsana, T., Tayamuthunagal,, J., Choczhavendhan, R. and Jayaraj,I.(2018) Biogas Production- A Review on Composition, Fuel Properties Feed Stock and Principles of Anaerobic Digestion. Renewable and Sustainable Energy. Reviews July 2018

[4] Chibueze, U., Okorie, N., Oriaku,O., John,I. and Peters, E. (2017) The Production of Biogas Using Cow Dung and Food Waste. International Journal of Materials and Chemistry. 20177 (2): 21 - 24.

[5] Dahoo, C., Read-Guernsey,J., Critchley, K. and Leeuwen,J.V.(2012) Pilot Study on the Impact of Biogas as a Fuel Source on Respiratory Health of Women in Rural Kenyan Smallholder. Dairy Farm.Journal of Environmental and Public Health.Volume 2012, Article ID 636298, 9 Pages. http:/dx.doi.org

[6] Ezekoye,V.A., Onah, D.U.,Offor, P.O. and Ezekoye, B.A. (2014) Characterization of Biogas Produced from Rice Husk and Algae Using a Metal Fixed- Dome Biodigester. Global Journal of Science Frontier Research: G.Bio- Tech and Genetics. Volume 14, Issue 1 Version 1.0 Year 2014.

[7] Freidmann(08 October

Biogaspraxisblog.Acidification of the Digester. Htt://friedmann-biogas praxis.com.

[8] Gurung, J.B. (1997) Review of Literature on Effects of Slurry Use on Crop Production. Final Report Submitted to the Biogas Support Program

[9] Han, W.B. and Chen, H. (2016) Study of Biogas Production of Joint Anaerobic Digestion with Excess Sludge and Kitchen. Waste.Procedia Environmental Sciences. Volume 35, 2016, pages $756-762$. 
[10] Herout, H., Malatak,J., Kacera,L. and Dlabaya,T.D.(2011) Biogas Composition Depending on the Type OF Biomass Used. Res. Agric. Eng. 57 (4),137, 2011.

[11] IbnAbubakar, B. S.U and Ismail, N. (2012) Anaerobic Digestion of Cow dung for Biogas Production

[12] Kasap, A., Aktas, R. Dulger, E. (2012) Economic and Environmental Impacts of Biogas. TarimMakinalariBilimiDergisi (Journal of Agricultural Machinery Science) 2012, 8 (30,271 277.

[13] Lawbury, J. (2001) Biogas Technology in India: More than Gandhi's Dream/ Online at www.ganesha.CO.UK/Articles as accessed

[14] Lopez- Ridaura,S., Van Der Werf, Paillat, J.M., Le Pris, B.(2009) Environmental Evaluation of Transfer and Treatment of Excess Pig Slurry by Life Cycle Assessment. Journal of Environment Management 90 (2) $1296-1304 \quad 2009$

[15] Lungkhimba, H.M., Karki, A.B. and Shrestha, J.N. (2010) Biogas Production from Anaerobic Digestion of Biodegradable Household Waste.Nepal Journal of Science and Technology. Vol.11 ,167 - 172. https://doi.org.

[16] Maiwada, N.A., Abdulkarim, H., Usman, ELL.andAbdullahi, S. (2014) The Role of Renewable Energy in Mitigating Deforestation and Climate Change in Nigeria. Journal of Natural Sciences Research.Vol. 4, No. 24, 2014 www.iiste.org.

[17] Nagamani, R. and Ramasamy, K. (1990) Biogas Production Technolgy: An Indian Perspective: Fermentation Laboratory, Department of Environmental Sciences. Tamil Nadu Agricultural University Coimbatore 641003 India.pp 61-62.

[18] Ogunsawa, O.Y. and Ajala, O.O. (2002) F irewood Crises in Lagos-Implication on the Suburban and Rural Ecosystem Management.In: Abu, J.E., Oni,P.O. and Popoola, L.(eds).Proceedings of the $28^{\text {th }}$ Annual Conference of Forestry Association of Nigeria at Akure, Ondo State, Nov. $4^{\text {th }}-8^{\text {th }}$ pp $257-264$.

[19] Okonkwo,U.C. and Onokwai, A.O. (2018) Comparative Study of the Optimal Ratio of Biogas Production from Various Organic Waste and Weeds for Digester/Restarted Digester. Journal of King Saudi University- Engineering Sciences. Volume 30, Issue 2, pages 123-129. Aprill 2018

[20] Onwuliri, F.C., Onyimba, I.A., Nwankwu I.A. (2013) Generation of Biogas from Cow DUNG, J BioremmedBiodeg 518:002.
[21] Recebli, Z., Selimli, S., Ozkaymak, M. Gonc, O. (2015) Biogas Production from Animal Manure. Journal of Engineering Sciences and Technology. Vol.10, No. 6 (2015) 722 - 729.

[22] Revielle, R. (1979) Energy Sources for Rural Development.Energy. Volume 4, Issue5, October 1979 pages $969-987$

[23] Shabab, M.R., Nazrul, M.I., Zonayed-ULL-Noor, A.K.M., Hossain, K.M.P. and Saha, D. (2015) BioSlurry Influences the Yield and Profitability of Radish. J. SylhetAgril. Univ., 2 (1): 9 - 14. 2015

[24] Smith, R. and Slater, F.M. (2010) The Effects of Organic and Inorganic Fertilizer Applications to Miscanthusgiganteus, Arundodonax and Phalarisarundinacea, When Grown as Energy Crop in Wales, UK.GCB Bioenergy. Vol.2,Issue 4 https://doi.org

[25] Torquati, B., Venanzi,S., Ciani, A., Diotalleri, F. and Tamburi,V.(2014) Environmental Sustainability and Economic Benefits of Dairy Farm Biogas Energy Production: A Cases Study in Umbria. Sustainability 2014, 6669 6713.,www.mdpi.co m/journaa/sustainability

[26] UNDP (2002) World Energy Assessment. United Nation Development Programme. United Nation Department of Economic and Social Affairs and World Energy Connect. New York: UNDP. World Energy Connect(WEC) 2002 Survey of World Energy Resources.

[27] Ukpai, P.A. and Nnabuchi, M.N. (2012) Comparative Study of Biogas Production from Cow Dung, Cow Pea and Cassava Peeling Using 45 Litres Biogas Digester. Advances in Applied Science.Research, 2012, 3(3), $1864-1869$ Available on line at www.pelagiaresearch- Library.com.

[28] Yahaya, D.B. and Ibrahim, T.G. (2012) Development of Rice Huisk Briquettes for Use as Fuel. Research Journal in Engineering and Applied Sciences. 1(2) 130- 133.www.energingresources.org

[29] Zaku, S.G., Kabir, A., Tuku, A.A. and Jimento I.G. (2013) Wood Fuel Consumption in Nigeria and the Energy Ladder: A Review of Fuel Wood Use in Kaduna State, Nigeria.Journal of Petroleum Technology and Alternative Fuels.Vol. 4(5), pp85-89.

[30] Zafar, S. (2012) 5:55 Agricultural Residue, Biomass Energy, Southeast

Asia.Follow@biomassconsultontwiter. 